Neurosurg Focus 13 (2):Article 11, 2002, Click here to return to Table of Contents

\title{
Indications for and benefits of lumbar facet joint block: analysis of 230 consecutive patients
}

\author{
Alan Bani, M.D., Uwe Spetzger, M.D., and Joachim M. Gilsbach, M.D. \\ Department of Neurosurgery, Klinikum Duisburg-Wedau, Duisburg; Department of Neurosurgery, \\ Municipal Hospital Klinikum, Karlsruhe; and Department of Neurosurgery, Medical Faculty, \\ University of Technology, Aachen, Germany
}

\begin{abstract}
Object. The authors evaluated the effectiveness of using a facet joint block with local anesthetic agents and or steroid medication for the treatment of low-back pain in a medium-sized series of patients.

Methods. Over a period of 4 years, the authors performed 715 facet joint injections in 230 patients with variablelength histories of low-back pain. The main parameter for the success or failure of this treatment was the relief of the pain. For the first injection-mainly a diagnostic procedure - the authors used a local anesthetic ( $1 \mathrm{ml}$ bupivacaine $1 \%$ ). In cases of good response, betamethasone was injected in a second session to achieve a longer-lasting effect.

Long-lasting relief of the low-back pain and/or leg pain was reported by 43 patients (18.7\%) during a mean followup period of 10 months. Thirty-five patients (15.2\%) noticed a general improvement in their pain. Twenty-seven patients $(11.7 \%)$ reported relief of low-back pain but not leg pain. Nine patients (3.9\%) suffered no back pain but still leg pain. One hundred sixteen patients $(50.4 \%)$, however, experienced no improvement of pain at all. In two cases the procedure had to be interrupted because of severe pain. There were no cases of infection or hematoma.

Conclusions. Lumbar facet joint block is a minimally invasive procedure to differentiate between facet joint pain and other causes of lower-back pain. The procedure seems to be useful for distinguishing between facet joint pain from postoperative pain due to inappropriate neural decompression after lumbar surgery. It can be also recommended as a possible midterm intervention for chronic low-back pain.
\end{abstract}

\section{KEY WORDS • facet joint • low-back pain • lumbar spine • pseudoradicular pain}

Typically hypertrophy and reactive remodeling of the articular processes are the degenerative changes seen in the lumbar facet joint in aging individuals. ${ }^{34}$ These facet joints have a close topographic relationship to delicate neural and vascular structures of the spinal canal. ${ }^{35}$ These degenerative changes are thought to cause low-back pain. Anatomically, the ipsilateral dorsal root ganglia supply the lumbar facet joint, segmentally and nonsegmentally. ${ }^{40,41}$ Some of the sensory fibers from the facet joint may pass through the paravertebral sympathetic trunk, reaching the L-1 and/or L-2 dorsal root ganglia. Therefore, facet joint pain originating from the lower lumbar levels may be distributed in L-1 and L-2 areas and is explained as "referred pain." An extensive network of small nerve fibers and free encapsulated nerve endings exists in the lumbar facet joint capsule. Low-threshold and high-threshold mechanoreceptors fire when the facet joint capsule is stretched or is subjected to localized compressive forces. ${ }^{40}$

The facet joint is subjected to high stress and strain ${ }^{2}$ and may be affected by rheumatoid arthritis, ankylosing spondylitis, osteoarthritis, and, rarely, synovial cysts and infections. Microtrauma to the facet joint may also cause pain. The resulting tissue damage or inflammation is likely to cause release of the content of the joint in which high-

Abbreviations used in this paper: $\mathrm{CT}=$ computerized tomography; MR = magnetic resonance. ly tissue-irritating properties affect the nerve endings in these joints, ${ }^{26}$ resulting in low-back pain. This may be in the form of pain in the inguinal region or sometimes of radicular pain secondary to irritation of the adjacent lumbar nerve root.

The main symptoms involved in facet joint syndrome are low-back pain with pseudoradicular radiation. Degenerative changes in the facet joint often occur long before they can be revealed on plain radiographs of the spine; these changes can be demonstrated on CT or MR imaging of lumbar spine. The diagnosis of facet joint syndrome is based primarily on one of exclusion. , $7,8,12,16,17,19,20,23,25,29,41,43$

Usually, the treatment of facet joint syndrome is to denervate the joint. Because of the aforementioned reasons, facet joint block therapy with steroid and cryoanalgesic agents is a routine procedure the goal of which is to reduce the inflammation, denervate the joint, and relieve the pain. ${ }^{22}$

\section{CLINICAL MATERIAL AND METHODS}

The study comprises 230 patients treated between 1997 and 2001. The duration of symptoms ranged from 1 week to many years. There were 147 men (64\%) and 83 women $(36 \%)$ who ranged in age from 32 to 81 years (mean age 55 years). The total number of the facet joints receiving injections was 715. All patients attended followed up for 


\section{A. Bani, U. Spetzger, and J. M. Gilsbach}

a period of 6 to 12 months (mean 10 months) after the last injection.

In 85 patients (37\%), the injection was performed for the conservative treatment of facet joint hypertrophy associated with chronic low-back pain in which the patient suffered pseudoradicular pain and had not previously undergone surgery. Sixty-five patients (28\%) suffered acute postoperative pseudoradicular pain, whereas 37 (16\%) suffered from chronic postoperative pseudoradicular pain. The facet joint block was performed in 187 patients $(81 \%)$ for the diagnosis and exclusion of facet joint disease associated pseudoradicular pain. There was a miscellaneous group of patients that included $28(12 \%)$ only low-back pain and $15(7 \%)$ in whom there was suspicion of segmental instability of a lumbar spinal segment.

For the injection we used a 22-gauge spinal needle $(0.7 \times 90 \mathrm{~mm}, 3.5 \mathrm{in})$. All injections were performed using fluoroscopy. After the needle was positioned, radiological documentation was performed. In six patients it was necessary to obtain arthrograms to determine the correct positioning of the needle because of the severe degenerative changes in the affected joints. The levels treated with blockade are shown in detail in Table 1. For the first injection, a local anesthetic was injected. In case of significant diminution of pain, a second injection was performed using betamethasone to include longer-lasting pain relief. All patients were ambulatory and underwent follow-up examination in the outpatient department.

The response to the facet block was analyzed according to a questionnaire given to the patient at the time of the injection; items included a self-rating assessment of the pain, duration, diurnal rhythm of the symptoms and frequency, subjective postinjection improvement and previous analgesic therapy, worsening of the symptoms over time, quality of life, and the pre- and postinjection degree of mobility.

In all patients, CT scans of the three lower lumbar segments were available. In choosing the most probable affected level, we depended mainly on the side of the pain and CT scanning in which bone-window sequences were obtained. Therefore, according to radiological changes revealed in the facet joints, in 107 patients $(46.5 \%)$ the so-called main affected levels and side were infiltrated selectively.

After standard skin sterilization, the spinal canula was introduced approximately 5 to $8 \mathrm{~cm}$ laterally from the spinous process in the level with the trunk rotated 30 to $45^{\circ}$ to the contralateral side.

The injection was performed once in 84 cases, (36.5\%) twice in $78(33.9 \%)$, three times in $36(15.7 \%)$ and more than three times in 32 cases $(13.9 \%)$ (Table 1$)$.

TABLE 1

Spinal levels treated with block

\begin{tabular}{lll}
\hline \hline Level & Unilat (\%) & Bilat $(\%)$ \\
\hline L5-S1 & $59(25.7)$ & $44(19.1)$ \\
L4-5 & $49(21.3)$ & $14(6)$ \\
L3-4 & $12(5.2)$ & \\
more levels & $52(22.6)$ & \\
\hline
\end{tabular}

\section{RESULTS}

\section{Symtom Relief}

In 14 patients, the joint could not be punctured because of calcification and partial ossification of the facet joint. In these cases, a pericapsular injection had to be performed. Long-lasting relief of the back and leg pain occurred in 43 patients $(18.7 \%)$, in whom only two or three injections were required. The pain did not recur during the 12-month follow-up period. All of these 43 patients suffered from acute postoperative pain either after microdiscectomy or osseous decompression secondary to lumbar spinal canal stenosis. In 27 patients (11.7\%) the radicular pain disappeared, but they still complained of back pain.

Nine patients $(3.9 \%)$ reported that they had no longer experienced back pain but still suffered sciatica. Thirtyfive patients $(15.2 \%)$ reported only a partial improvement of the back and leg pain (Table 2).

One hundred sixteen patients $(50.4 \%)$, however, reported no improvement of any symptom, despite correct positioning of the spinal cannula within the joint (Table 3).

\section{Procedure-Related Complications}

In eight patients (3.5\%) the wrong level above or below the planned joint was inadvertently injected. After explaining this to the patient, the injection was repeated the next day. Six patients $(2.6 \%)$ reported a transient increase of pain directly after the injection. Two patients $(0.9 \%)$ suffered from transient radicular sensory changes. In three patients $(1.3 \%)$, the dura mater was accidentally punctured, causing temporary paraplegia in one patient that resolved within 3 hours; the two others reported only headache, probably resulting from cerebrospinal fluid leakage, which resolved spontaneously after 48 hours. In two cases the injection was interrupted because the patient experienced severe pain. No infection or symptomatic hematomas were noted (Table 4).

\section{DISCUSSION}

In this study the group of patients that benefited from facet joint block contained mainly individuals with acute postoperative uncontrollable local and pseudoradicular pain. In these patients, because CT scanning excluded the possibilities of recurrent disc prolapse and insufficient de-

TABLE 2

Outcome according to patient-rated responses

\begin{tabular}{|c|c|c|}
\hline $\begin{array}{l}\text { Outcome } \\
\text { Category }\end{array}$ & $\begin{array}{c}\text { No. of } \\
\text { Patients }(\%)\end{array}$ & Criteria \\
\hline excellent & 43 (18.7) & $\begin{array}{l}\text { complete relief of back \& lower-extremity } \\
\text { pain; no further analgesics necessary; no } \\
\text { pain during follow up of } 6-12 \text { mos }\end{array}$ \\
\hline good & 27 (11.7) & $\begin{array}{l}\text { disappearance of lower-extremity pain, but } \\
\text { not low-back pain; mild analgesics used }\end{array}$ \\
\hline fair & $44(19.1)$ & $\begin{array}{l}\text { only partial relief of low-back pain and } \\
\text { lower-extremity pain }\end{array}$ \\
\hline poor & $116(50.4)$ & $\begin{array}{l}\text { no relief, unable to work; strong analgesic } \\
\text { used regularly }\end{array}$ \\
\hline
\end{tabular}


Indications and benefits of lumbar facet joint block

TABLE 3

Summary of complications in 22 patients

\begin{tabular}{lcl}
\hline \hline \multicolumn{1}{c}{ Complications } & $\begin{array}{c}\text { No. of } \\
\text { Patients }\end{array}$ & \multicolumn{1}{c}{ Reaction } \\
\hline wrong level injected & 8 & injection repeated \\
transient increase of pain & 6 & no specific therapy \\
puncture of subarachnoid space & 3 & no specific therapy \\
severe pain & 2 & interruption \\
transient hypesthesia & 2 & no therapy \\
transient paraplegia & 1 & no therapy \\
\hline
\end{tabular}

compression of the spinal canal after operation for spinal canal stenosis, only the operated level and side received selective injection. In $43(66 \%)$ of 65 patients the facet joint block was successful in relieving pain directly and in maintaining this relief by follow up. Because most cases of acute back and leg pain improve within few weeks, ${ }^{1,42}$ it is uncertain whether the facet joint block induced longlasting diminution of the pain or whether was related to the natural history of the disease. In these cases, the facet joint block served as a therapeutic procedure. The cause of pseudoradicular pain after microdiscectomy and osseous decompression in spinal stenosis is most likely the result of reduction of the medial facet joint with opening and release of contents of the joint. The contents of the joint cause irritation of the adjacent nerve root and therefore pain. ${ }^{26,36}$ Symptoms in these patients responded to facet joint injection.

In other patients, the indication was not clearcut. All injections were chosen by exclusion. It is a fact that the facet joint is rarely alone responsible for low-back pain. Provided other causes are excluded, there is an indication to perform a diagnostic facet joint injection, ${ }^{21,31,36}$ even in cases of radicular pain in the absence of nerve root compression. Typically, there is no relation in most of the cases between the extent of the scar tissue demonstrated on CT scans and the degree of pain experienced by the patient. ${ }^{32}$ In some cases of persistent postoperative pain, especially back pain, extensive back muscle injury may be a cause..$^{18}$ This is especially the case following extensive and multisegmental laminectomy, as would be performed in multisegmental lumbar spinal canal stenosis. In these cases the lumbago predominates the symptomatology. These patients are not candidates for facet joint injections.
Despite the diversity of symptoms, it was possible in 121 patients $(52.6 \%)$ to identify and treat by injection one level and side selectively. Unfortunately CT scans of the lumbar spine do not reveal early degenerative changes in the facet joint, and they were unable to demonstrate facet joint inflammation. Using sophisticated methods like single-photon emission CT scanning to identify the affected joint ${ }^{6}$ is expensive, time consuming, and in our opinion unnecessary.

On the other hand, if the clinical picture and the radiological features do not help to indicate the one level or side to be treated, it is necessary to inject the two or three lower levels bilaterally. The effect of multisegmental injections is questionable. Additionally, it was an unpleasant experience for $22.6 \%$ of the patients in this series.

There was no need for the infiltration of the skin with a local anesthetic. One predictor of an optimum position of the cannula is the fact that we cannot inject more than 1 $\mathrm{ml}$ into the joint. A periarticular injection is also helpful in some of the cases in which facet joint syndrome is suspected; however, the effect is short with a mean duration of 1 week (in 14 patients [6\%] in this series) in contrast to an exact intraarticular injection that may yield 1 to 3 months of relief or longer. Despite great care in inserting the spinal needle, the first author (A.B.) punctured the dura in two of the first 10 cases, which can be explained as a learning curve.

Postoperative pseudoradicular pain may be minimized by making an intraoperative intraarticular injection of corticosteroid into the opened joint. Similar results can be obtained if one also coagulates the joint, although there is no long-term difference in the response between percutaneous facet joint coagulation and facet joint injection with corticosteroids. ${ }^{16,17}$

All except two injections were performed using fluoroscopy. With this simple method it was possible to visualize the joint in 227 patients (99\%) in the oblique position so that the spinal needle could be introduced. Only in three cases was an additional CT scan required to determine the exact localization of the cannula in the joint, because of obesity, scoliosis, and interbody cages, respectively. Performing the injection under fluoroscopy has many advantages including less exposure to radiation, the short duration of the procedure, and lower costs. A percutaneous blind injection of the facet joint is not recommend$\mathrm{ed}^{34}$ and was practically not possible in this series, because the position of the cannula had to be corrected at least once in all the 715 joints injected.

TABLE 4

Summary of data in 116 patients in whom symptoms did not respond to facet joint injections

\begin{tabular}{|c|c|c|c|c|}
\hline Signs \& Symptoms & $\begin{array}{c}\text { No. of } \\
\text { Patients } \\
\text { W/Out } \\
\text { Response }\end{array}$ & $\begin{array}{l}\text { CT or MR } \\
\text { Finding }\end{array}$ & Conclusion & $\begin{array}{c}\text { Pain } \\
\text { Improvement }\end{array}$ \\
\hline $\begin{array}{l}\text { chronic back pain w/ or w/out } \\
\text { radiation }(>1 \mathrm{yr})\end{array}$ & 44 & $\begin{array}{l}\text { degenerative changes, no disc prolapse, } \\
\text { no spinal canal stenosis }\end{array}$ & conservative therapy & none \\
\hline chronic postdiscectomy syndrome & 37 & scar tissue $\&$ in 7 recurrent disc prolapse & 7 reop & 5 improved \\
\hline spinal canal stenosis & 29 & spinal canal stenosis & $\begin{array}{l}\text { laminotomy \& osseous decom- } \\
\text { pression }\end{array}$ & $\begin{array}{l}19 \mathrm{w} / \text { good results, } 2 \\
\text { w/ no improvement }\end{array}$ \\
\hline $\begin{array}{l}\text { acute pain after percutaneous } \\
\text { nucleotomy }\end{array}$ & 6 & $\begin{array}{l}\text { no disc prolapse, no signs of } \\
\text { disc prolapse }\end{array}$ & $\begin{array}{l}\text { wrong indication (nerve root } \\
\text { injury?) }\end{array}$ & none \\
\hline
\end{tabular}




\section{A. Bani, U. Spetzger, and J. M. Gilsbach}

TABLE 5

Questionable responses to injection therapy in 28 patients

\begin{tabular}{|c|c|c|c|c|}
\hline Indication & $\begin{array}{l}\text { No. of } \\
\text { Patients }\end{array}$ & CT or MR Finding & Level Injected & Comment \\
\hline unspecific back pain & 9 & $\begin{array}{l}\text { multisegmental lumbar } \\
\text { facet joint degeneration }\end{array}$ & $\begin{array}{l}\mathrm{L} 3-4, \mathrm{~L} 4-5, \text { \& L } 5-\mathrm{S} 1 \\
\text { bilaterally }\end{array}$ & very unpleasant, short improvement \\
\hline $\begin{array}{l}\text { pain after multiple disc } \\
\text { ops }(>4)\end{array}$ & 4 & $\begin{array}{l}\text { scar tissue, degenerative } \\
\text { disc space }\end{array}$ & op level & no improvement \\
\hline $\begin{array}{l}\text { analgesic addiction after } \\
\text { multiple disc ops }\end{array}$ & 4 & no recurrent disc prolapse & op level & no improvement \\
\hline $\begin{array}{l}\text { pain after percutaneous } \\
\text { neucleotomy }\end{array}$ & 4 & $\begin{array}{l}\text { protrusion, no neural com- } \\
\text { pression }\end{array}$ & op level & $\begin{array}{l}2 \text { no improvement, } 1 \text { op interrupted } \\
\text { due to pain }\end{array}$ \\
\hline $\begin{array}{l}\text { extreme obesity w/ } \\
\text { low-back pain }\end{array}$ & 7 & $\begin{array}{l}\text { severe lumbar degenerative } \\
\text { changes }\end{array}$ & $\begin{array}{l}\text { L3-4, L4-5, \& L5-S1 } \\
\quad \text { bilaterally }\end{array}$ & $\begin{array}{l}\text { very unpleasant, } 2 \text { short improvement, } \\
2 \text { no improvement }\end{array}$ \\
\hline
\end{tabular}

In 28 patients the facet joint injections were performed as an additional attempt at pain therapy, because other alternatives were insufficient. In these patients, the response to the injection was questionable (Table 5).

In no case was a simultaneous facet joint and periradicular injection performed. The periradicular injection may perhaps be helpful in cases of suspected postoperative periradicular fibrosis and venous congestion in the lumbar root canal nerve root, which is thought to be one of the causes of low-back pain with radicular irritation., ${ }^{413}$

Because the facet joint behaves similarly to a myofacial trigger point, the effect of a local anesthetic usually lasts longer than its pharmacological effect. In this series, however, there were 28 patients $(12.2 \%)$ who reported alleviation of the symptoms, which we could not correlate with the effect of the facet joint injection; the indication was unclear. All of them reported marked diminution of symptoms many days after the first injection (local anesthetic) perhaps due to placebo effect. Although the lumbar facet joint as a source of low-back pain becomes more confusing the more clinical studies that are reported, $5,9,10,14,17,19,25$, $33,36,38,39$ the facet joint may be responsible for at least some degree of low-back pain with pseudoradicular and radicular radiation. ${ }^{2,3,7,8,11,12,15,17,21,24,26-28,30,37,43}$ Experimentally, a marked reduction of the nerve activity occurs in facet tissue injected with local anesthetic and corticosteroid agents. ${ }^{2}$ Therefore, percutaneous facet joint injection aims to denervate the facet joint, from which the pain seems to originate.

\section{CONCLUSIONS}

The primary role of facet joint block should be diagnostic. It can also be used as an additional therapy for suspected facet joint syndrome in patients in whom symptoms fail to respond to conservative treatments of lowback pain.

Although our results for the symptomatic relief of pain have been roughly graded, we think it is mainly because of the nature of the disease. Our clinical impression is that this method is beneficial and warrants continuous application.

Finally, successful rehabilitation of the patients should be feasible due to prolonged pain relief provided by this treatment.

\section{References}

1. Anderson GB, Svensson HO, Oden A: The intensity of work recovery in low back pain. Spine 8:880-884, 1983

2. Cavanaugh JM, Ozaktay AC, Yamashita HT, et al: Lumbar facet pain: biomechanics, neuroanatomy and neurophysiology. J Biomech 29:1117-1129, 1996

3. Cavanaugh JM, Ozaktay AC, Yamashita T, et al: Mechanism of low back pain: a neurophysiologic and neuroanatomic study. Clin Orthop 335:166-180, 1997

4. Cooper RG, Freemont AJ, Hoyland JA: Herniated intervertebral disc-associated periradicular fibrosis and vascular abnormalities occur without inflammatory cell infiltration. Spine 20: 591-598, 1995

5. Cowan NC, Bush K, Katz DE, et al: The natural history of sciatica: a prospective radiological study. Clin Radiol 46:7-12, 1992

6. Dolan AL, Ryan PJ, Arden NK, et al: The value of SPECT scans in identifying back pain likely to benefit from facet joint injection. Br J Rheumatol 35:1269-1273, 1996

7. Eisenstein SM, Parry CR: The lumbar facet joint arthrosis syndrome. Clinical presentation and articular surface changes. J Bone Joint Surg Br 69:3-7, 1987

8. el-Khoury GY, Renfrew DL: Percutaneous procedures for the diagnosis and treatment of lower back pain: Diskography, facet-joint injection, and epidural injection. AJR 157:685-691, 1991

9. Gangi A, Dietemann JL, Mortazavi R, et al: CT-guided interventional procedures for pain management in the lumbosacral spine. Radiographics 18:621-633, 1998

10. Goupille P, Fitoussi V, Cotty P, et al: [Injection into the lumbar vertebrae in chronic low back pain. Results in 206 patients.] Rev Rhum Ed Fr 60:797-801, 1993 (Fr)

11. Hadler NM: The disabling backache. An international perspective. Spine 20:640-649, 1995

12. Helbig T, Lee CK: The lumbar facet syndrome. Spine 13: 61-64, 1988

13. Hoyland JA, Freemont AJ, Jayson MI: Intervertebral foramen venous obstruction. A cause of periradicular fibrosis? Spine 14: 558-568, 1989

14. Humke T, Grob D, Dvorak J, et al: Translaminar screw fixation of the lumbar and lumbosacral spine. A 5-year follow-up. Spine 23:1180-1184, 1998

15. Jackson RP: The facet syndrome. Myth or reality? Clin Orthop 279:110-121, 1992

16. Jerosch J, Castro WH, Halm H, et al: [Long-term results following percutaneous facet coagulation.] Z Orthop Ihre Grenzgeb 131:241-247, 1993 (Ger)

17. Jerosch J, Castro WH, Liljenqvist U: Percutaneous facet coagulation: indication, technique, results, and complications. Neurosurg Clin N Am 7:119-134, 1996 
18. Kawaguchi Y, Matsui H, Tsuji H: Back muscle injury after posterior lumbar spine surgery. Part 1: Histologic and histochemical analyses in rats. Spine 19:2590-2597, 1994

19. Lilius G, Laasonen EM, Myllynen P, et al: Lumbar facet joint syndrome. A randomised clinical trial. J Bone Joint Surg Br 71:681-684, 1989

20. Lilius G, Laasonen EM, Myllynen P, et al: [Lumbar facet joint syndrome. Significance of non-organic signs. A randomized placebo-controlled clinical study.] Rev Chir Orthop Reparatrice Appar Mot 75:493-500, 1989 (Fr)

21. Lippitt AB: The facet joint and its role in spine pain. Management with facet joint injections. Spine 9:746-750, 1984

22. Lloyd JW, Bernard JD, Glynn CJ: Cryoanalgesia. A new approach to pain relief. Lancet 2:932-934, 1976

23. Lynch MC, Taylor JF: Facet joint injection for low back pain. A clinical study. J Bone Joint Surg Br 68:138-141, 1986

24. Maistrelli GL, Vaughan PA, Evans DC, et al: Lumbar disc herniation in the elderly. Spine 12:63-66, 1987

25. Marks RC, Houston T, Thulbourne T: Facet joint injection and facet nerve block: a randomized comparison in 86 patients with chronic low back pain. Pain 49:325-328, 1992

26. Marshall LL, Trethewie ER, Curtain CC: Chemical radiculitis. A clinical, physiological and immunological study. Clin Orthop 129:61-67, 1997

27. Mirkovic SR, Schwartz DG, Glazier KD: Anatomic considerations in lumbar posterolateral percutaneous procedures. Spine 20:1965-1971, 1995

28. Miyake R, Ikata T, Katoh S, et al: Morphologic analysis of the facet joint in the immature lumbosacral spine with special reference to spondylolysis. Spine 21:783-789, 1996

29. Mooney V, Robertson J: The facet syndrome. Clin Orthop 115:149-156, 1976

30. Nachemson A: Intradiscal measurements of $\mathrm{pH}$ in patients with lumbar rhizopathies. Acta Orthop Scand 40:23-42, 1969

31. North RB, Kidd DH, Zahurak M, et al: Specificity of diagnostic nerve blocks: a prospective, randomized study of sciatica due to lumbosacral spine disease. Pain 65:77-85, 1996

32. Nygaard OP, Kloster R, Dullerud R, et al: No association between peridural scar and outcome after lumbar microdiscectomy. Acta Neurochir 139:1095-1100, 1997
33. Oudenhoven RC: The role of laminectomy, facet rhizotomy, and epidural steroids. Spine 4:145-147, 1979

34. Purcell-Jones G, Pither CE, Justins DM: Paravertebral somatic nerve block: a clinical, radiographic, and computed tomographic study in chronic pain patients. Anesth Analg 68:32-39, 1989

35. Rauschning W: Normal and pathologic anatomy of the lumbar root canals. Spine 12:1008-1019, 1987

36. Revel M, Poiraudeau S, Auleley GR, et al: Capacity of the clinical picture to characterize low back pain relieved by facet joint anesthesia. Proposed criteria to identify patients with painful facet joints. Spine 23:1972-1977, 1998

37. Revel ME, Listrat VM, Chevalier XJ, et al: Facet joint block for low back pain: identifying predictors of a good response. Arch Phys Med Rehabil 73:824-828, 1992

38. Schleifer J, Fenzl G, Wolf A, et al: [Treatment of lumbar facet joint syndrome by CT-guided infiltration of the intervertebral joints.] Radiologe 34:666-670, 1994 (Ger)

39. Schleifer J, Kiefer M, Hagen T: [Lumbar facet syndrome. Recommendation for staging before and after intra-articular injection treatment.] Radiologe 35:844-847, 1995 (Ger)

40. Suseki K, Takahashi Y, Takahashi K, et al: CGRP-immunoreactive nerve fibers projecting to lumbar facet joints through the paravertebral sympathetic trunk in rats. Neurosci Lett 221: 41-44, 1996

41. Suseki K, Takahashi Y, Takahashi K, et al: Innervation of the lumbar facet joints. Origins and functions. Spine 22:477-485, 1997

42. Vallfors B: Acute, subacute and chronic low back pain: clinical symptoms, absenteeism, and working environment. Scand J Rehabil Med Suppl 11:1-98, 1985

43. van Tulder MW, Koes BW, Bouter LM: Conservative treatment of acute and chronic nonspecific low back pain. A systematic review of randomized controlled trials of the most common interventions. Spine 22:2128-2156, 1997

Manuscript received June 17, 2002.

Accepted in final form July 3, 2002.

Address reprint requests to: Alan Bani, M.D., Department of Neurosurgery, Klinikum Duisburg-Wedau, zu den Rehwiesen 9, 47055 Duisburg, Germany. email: drabani@msn.com. 